\title{
Anxiety, Time, and Agency
}

Felix Berenskoetter

SOAS University of London

Forthcoming in International Theory (Accepted Version, February 2020)

\begin{abstract}
This article scrutinizes two concepts central to the ontological security framework, agency and anxiety. Its point of departure is the view that conceptions of agency are expressed in the attempt to become ontologically secure, which requires a more careful look at how humans try to satisfy the need for a 'stable sense of Self' by putting in place 'anxiety controlling mechanisms'. This, in turn, raises the question what these mechanisms are supposed to control, which shifts attention to the concept of 'anxiety'. Going back to Kierkegaard's original treatment and Heidegger's existential phenomenology, the article reviews the emergence of anxiety as a core feature of the human condition and highlights what it calls the 'anxiety paradox': the tendency of reflexive humans facing the freedom of being in time to attach themselves to constructs that provide a sense of temporal continuity, or certainty. The article argues that the existing ontological security literature is trapped in this paradox and therefore cannot account for radical forms of agency.
\end{abstract}

Keywords: Anxiety, Agency, Temporality

An increasing number of constructivist IR scholars use the concept of ontological security to explain behaviour in international relations. Adopted from Anthony Giddens, ${ }^{1}$ they understand ontological security as the feeling of having a 'stable sense of Self', which is considered a basic human need. Such attention to the psychological sensibilities of political actors offers a fruitful alternative to the realist emphasis on physical security as the primary concern. This article takes a closer look at two concepts central to the ontological security framework that remain subdued in the literature, agency and anxiety.

Exploring conception(s) of agency is important for analytical, practical and ethical reasons; ${ }^{2}$ it touches on fundamental questions of free will and determinism, probing not only how individuals and collectives do act, but also how they could and should act. Notions of agency are thus central to theories of world politics, ${ }^{3}$ not least because they help account for phenomena of change, an issue that has long bedeviled the social constructivist literature. ${ }^{4}$ In approaching conceptions of agency offered by the ontological security framework it is important to separate out two motivational assumptions: (i) that having ontological security is a precondition for action, and (ii) that seeking ontological security is driving choices and behaviour. While the existing literature tends to highlight the first, this article holds that we need

\footnotetext{
${ }^{1}$ Giddens 1984, 1991.

${ }^{2}$ Emirbayer and Mische 1998.

${ }^{3}$ Wendt 1987; Berenskoetter 2018.

${ }^{4}$ Flockhart 2017.
} 
to shift attention to the second reading, namely agency of seeking ontological security. If we take the existentialist roots of the framework seriously, conceptions of agency cannot be derived from being ontologically secure, but are expressed in the attempt to become ontologically secure.

I explore the nature of this agency and its limitations by taking a careful look at the need for a 'stable sense of Self' and how it is satisfied. I do so by revisiting Giddens' notion, building on R. D. Laing and Erik Erikson, that ontological security is obtained by putting into place "anxiety controlling mechanisms." If seeking ontological security aims at 'controlling anxiety" by putting in place certain 'mechanisms', we must ask about the nature of those mechanisms and who is able to create, control, challenge and change them. But we still need to dig deeper: to meaningfully address the nature of these mechanisms and the agency behind them we need to have an understanding what they are supposed to control. We must grasp the origin and nature of anxiety. Thus, exploring the concept of anxiety and how it functions in the ontological security framework is the second aim of this article. In fact, it is the more foundational issue and needs to be tackled first. The article does this by focusing on the temporal dimension of being/the Self. ${ }^{6}$ Going back to Kierkegaard's original treatment and Heidegger's existential phenomenology, the article reviews the emergence of anxiety as a core feature of the human condition and directs attention to what I call the 'anxiety paradox': the tendency of reflexive humans facing the freedom of being in time to attach themselves to constructs that provide a sense of temporal continuity, or certainty. I argue that because the existing ontological security literature is trapped in (parts of) this paradox, it cannot account for radical forms of agency.

This argument connects with voices critical of the ontological security scholarship, specifically of the assumption that a stable sense of Self is a universal need and standard accounts how this need is met. ${ }^{7}$ Yet, I remain sympathetic to the framework to probe whether, perhaps, its underlying logic allows for a broader scope that can accommodate more diverse kind(s) of agency. The discussion proceeds in five steps. It starts by directing attention to the temporal sources of anxiety and its status as a foundational sentiment, or mood. It then outlines what I call the 'anxiety paradox', followed by a brief review of prominent strategies of controlling anxiety. The fourth step discusses three types of agency underpinning the anxiety paradox. The fifth part then outlines two potential avenues for integrating a reading of radical agency into the ontological security framework, followed by a short conclusion.

\section{From Uncertainty to Anxiety}

An engagement with the concept of anxiety requires recovering the existentialist foundations of the ontological security framework and discerning how 'anxiety' is related to and differs from the closely related concepts of 'uncertainty' and 'fear'. My starting point is to see human existence embedded in three worldly dimensions, the social, the spatial and the temporal. A fundamental feature of this condition is uncertainty: we cannot read minds of others and don't really know what they think or feel (the social); historical accounts are contested and we don't really know what the future brings (the temporal); we are living on a planet containing an abundance of matter, whose moves we cannot control, and which is floating in an infinite space of which we know very, very little (the spatial). While humans have always tried to reduce these uncertainties by learning more about their social, temporal and spatial environment, ultimately

\footnotetext{
${ }^{5}$ Giddens 1984, 50.

${ }^{6}$ I refer to 'being' and 'Self', rather than 'identity'.

${ }^{7}$ Rossdale 2015a; Lebow 2017.
} 
we have to accept that our knowledge is limited. We have to live with uncertainty. The question arising, then, is how uncertainty affects feeling, thinking and acting, and how it structures relations.

In the field of IR, realist scholars have traditionally paid attention to this question drawing on Hobbesian logic. In their account, uncertainty constitutes a "condition of epistemological indeterminacy" ${ }^{\prime}$ in which states co-exist in continual danger of being attacked. While uncertainty is linked to an unknown future, realists place emphasis on the social dimension, that is, the inability to truly know the intentions of other states and what they will do with the capabilities at their disposal. Uncertainty thus generates a sense of physical insecurity and is expressed in distrust and fear as defining features of social relations. Fear of a future in which only death is certain turns into fear/distrust of the other, which provides the rationale for political arrangements that enable a life without such fear. ${ }^{9}$ Whereas for Hobbes the solution is a social contract in the form of the Leviathan, realists argue that rational actors must protect themselves by maximizing their military power.

Ontological security scholarship offers a different approach by holding that uncertainty generates anxiety. Drawing on existentialist philosophy, this move is grounded in a logic that operates with a different conception of the subject and opens the door to a broader set of behavioural implications. I outline this logic here through Martin Heidegger's discussion of the phenomenon of anxiety in his existentialist treatise 'Being and Time' [Sein und Zeit], which had a major influence on the development of the ontological security framework. Like Hobbes, Heidegger identifies uncertainty as a central factor structuring the human condition. Yet his discussion about the nature of uncertainty and its impact on being and social life takes a different route from Hobbes. ${ }^{10,11}$ For the purpose at hand two aspects stand out. First, Heidegger foregrounds the temporal dimension as the most important aspect affecting our understanding what it means to be, and notes that one's own death is the one thing affecting being in a unique way. Death signifies the moment after which 'being' becomes impossible in the phenomenological sense, ${ }^{12}$ and it is only in death that the life span is complete. Until then, being remains incomplete. Rather than a finished whole, such as the state in the realist imaginary, the 'Self' - which in IR terms usually takes the form of a political collective - is always in the process of coming-into-being, or becoming.

Second, in Heidegger's existentialist phenomenology, being in the world is significantly shaped by experience. It is impossible, however to have an experience of what it means to die, as even the death of a close family member is an experience that, ultimately, cannot be shared. ${ }^{13}$ The implications of this seemingly trivial point are profound, because it allows problematizing the link between death and fear by pointing out that without being able to experience death it is impossible to know what to fear. We know that 'death' will happen, eventually, which makes it an integral part of life, but we are unable to comprehend/grasp it as a meaningful thing for ourselves. And so, while we can be certain about our inescapable finitude, we cannot really fear that which brings death about. We cannot 'know' the existential threat in the phenomenological sense. It is potentially everywhere and can appear out of nowhere, ${ }^{14}$ making contingency an

\footnotetext{
${ }^{8}$ Williams 2005, 25.

${ }^{9}$ Epstein 2013.

${ }^{10}$ Odysseos 2002.

${ }^{11}$ See, however, Rumelili 2020.

12 Heidegger 1953, 250.

${ }^{13}$ Ibid., §47, §52.

${ }_{14}$ Ibid., §40, 186, §52, 258.
} 
inescapable feature of being in the world. The human response to this condition, Heidegger argues, is not fear but anxiety. ${ }^{15}$ Generated by the unknowability of death and of the future more generally, he identifies anxiety as the foundational sentiment or mood [Befindlichkeit] of the human condition from which more concrete wills or desires spring. ${ }^{16}$

In short, whereas in the realist framework the actor is imagined as a complete whole (a clearly delineated sovereign state) and knows what to fear (other states with military resources), the actor in an ontological security framework is incomplete and conditioned by their inability to know, by anxiety. To understand what kind(s) of agency this generates, let us go over some accounts on the situations in which anxiety emerges and the human response to it.

\section{The Emergence of the Anxious Mind and the Anxiety Paradox}

Awareness of radical contingency is not a phenomenon of post-modern times. Rather, at least in the accounts of Western philosophy, it emerges at the moment of enlightenment - "man's emergence from his self-imposed...inability to use one's own understanding” to use Kant's famous words. ${ }^{17}$ That is, anxiety enters our world once we become self-conscious and reflexive subjects. In the words of Alastair Hannay ${ }^{18}$ "Anxiety...is the mood in which human beings awaken to the peculiarly exposed vantage point they 'enjoy' by virtue of their specifically reflective form of awareness”. As this 'awakening' is considered a momentous occasion in the history of human development, writers have located its occurrence in significant contexts. A brief look at prominent examples illustrates the process and reveals a paradox at the heart of it.

Soren Kirkegaard in his discussion of the Concept of Anxiety chooses the biblical story of Genesis as the setting. In this account, Adam living in the Garden of Eden is an innocent and ignorant being in a state of "peace and repose"; ${ }^{19}$ he feels no anxiety. This changes when Adam encounters the tree of knowledge. By eating the apple Adam looses his innocence/ignorance and not only brings sin and death into the world, but also anxiety. In fact, in Kierkegaard's account anxiety arises already through the very prohibition of eating from the tree, because this constitutes the awareness that things could be otherwise: "the prohibition makes him anxious, because it awakens in him freedom's possibility." ${ }^{20}$ Kierkegaard thus sees anxiety coming not out of the inability to grasp ones' finitude, but out of the awareness of having the ability to choose and, hence, of the infinitude of possibilities open to human beings. As he puts it "anxiety is freedom's actuality as the possibility of possibility." 21 Although Kierkegaard focuses on morality rather than temporality as the framework within which anxiety arises, he makes an important observation: in the temptation to taste the forbidden fruit, Adam feels both drawn to and wants to flee from the freedom of possibility and, thus, anxiety. Here Kierkegaard identifies

\footnotetext{
${ }^{15}$ Heidegger discusses the concept of anxiety through the notions of Angst and Sorge. It is common to translate Angst as 'anxiety' and Sorge as 'care’, which can be misleading as Sorge has a double meaning in German, denoting both 'care' (the German Fürsorge) and 'anxiety'. As I read him, Heidegger uses Sorge mainly in the latter sense, as a mood that contains and, in rare moments turns into Angst, but is different from it.

16 Heidegger 1953, §41.

${ }^{17}$ Although the enlightenment is a core theme in liberal thought, I do not mean to present a story of progress or suggest that 'Western civilization' is the home of reflexivity.

${ }^{18}$ Hannay 2014, xxiii.

${ }^{19}$ Kirkegaard (1844) 2014, 50.

${ }^{20}$ Ibid., 54.

21 Ibid., 51.
} 
what he calls the dialectic property of anxiety "as a sympathetic antipathy and an antipathetic sympathy" (Ibid, 51, italics in original).

The dialectic in the human attitude towards 'freedom's possibility' - of both feeling drawn to and wanting to flee from anxiety - is also found in readings of humans as temporal beings. It is illustrated in accounts by Max Horkheimer and Theodor Adorno, ${ }^{22}$ as well as John Gunnell, ${ }^{23}$ who revoke another 'place of origin' popular in Western philosophy, ancient Greece. In this context, lives were embedded in myths and rythms of nature, in a cosmic creation ordered by the Gods. Humans did not see themselves as masters of their own fate and did not (need to) reflect on their own finitude; it was a world without anxiety. ${ }^{24}$ This changes in Homer's epic poems the Iliad and Odyssey, where protagonists like Ulysses are given a sense of uniqueness and become aware of their mortality, partially claiming responsibility for their actions. However, the journey is also a struggle, exemplified in Ulysses' deliberate alienation from and simultaneous surrender to the forces of nature during the encounter with the sirens. ${ }^{25}$ Temporal self-consciousness remains weak, as human existence is still oriented towards a tragic past from which there is no escape, and the possibility of immortality is maintained through the performance of god-like heroic deeds. ${ }^{26}$ This move of grasping but not fully embracing the unique temporal nature of human existence is also visible in Plato's Republic. At one level, Plato criticizes Athenian society as ordered by values derived from myth and folk memory and emphasizes to instead embrace the human ability to shape the future. Plato famously does so by imagining five types of polis, yet in his account eternity can still be reached through the philosophers' ability to envision and create a just order in which the soul can be embedded. That is, the enlightened human breaks with the gods, only to be tied to the polis as a permanent home, "an imperishable space" that transcends human time. ${ }^{27}$

The emergence of nationalism, the (re)formation of self-consciousness on the collective level, offers another exemplary setting. In Imagined Communities, Benedict Anderson ${ }^{28}$ attributes the emergence of nationalism in Europe and Latin America to the spread of the novel and the newspaper. While often reduced to an argument about the rise of the publishing industry driven by capitalism's search for new markets, a crucial component of Anderson's argument is that the impact of the printed press was rooted in a transformed conception of time. Anderson describes societies where the decline of monarchical rule went hand in hand with the decline of cosmic or 'Messianic time' and the emergence of secular 'empty time' (Benjamin) of modernity. This time was made meaningful by the printed press, which according to Anderson satisfied a demand for 'simultaneity' among individuals trying to find their place in this new temporal universe. By reading the same stories in newspapers and novels, these mediums created "the idea of a sociological organism" moving calendrically through time, a shared narrative that connected individuals to a 'nation' on a temporal plane. ${ }^{29}$ Similar moves can be observed in anticolonial struggles when colonized communities reject the temporal frame imposed on them by the colonizer and try to recover, or recreate, their own conception of being in time. Sankaran Krishna points to the link between such a collective narrative that provides "a content, a history,

\footnotetext{
${ }^{22}$ Horkheimer and Adorno (1947) 1988.

${ }^{23}$ Gunnell 1987.

${ }^{24}$ Horkheimer and Adorno 1988, 33, 50ff; Gunnell 1987, $25 \mathrm{ff}$.

${ }^{25}$ Horkheimer and Adorno 1988, 55, Exkurs 1.

${ }^{26}$ Gunnell 1987, 79-87.

${ }^{27}$ Ibid., 115.

${ }^{28}$ Anderson 2006.

${ }^{29}$ Ibid., 26.
} 
a meaning, and a trajectory” for an independent society and cartographic representations affirming their place in a world of territorially sovereign states "as a timeless essence.”30,31

Sweeping as these accounts may be, they illustrate a peculiar dynamic: reflexive humans gain temporal self-consciousness through emancipation from mythical, cosmic or colonial orders, yet in the process they create new knowledge which, as Horkheimer and Adorno famously argue, is not so different from the myth it sought to replace. If we read both the discarding and the refashioning of temporal orders as resulting from choices made by reflexive subjects, we are presented with a behavioral paradox: the subject strives for the ability to organize its being in time yet is reluctant to fully accept the newfound freedom. Awareness of being positioned in finite time and recognizing that past and future are dimensions affected by, and affecting, human activity, leads to the formulation of 'post-mythical' conceptions of time that do not embrace contingency but, instead, convey a desire to hold on to some sort of continuity and coherence by re-inventing a transcendental layer with an eternal perspective into which worldly existence is embedded. This, then, is what I call the anxiety paradox: Having wrestled agency from the gods, humans use this agency to recreate perhaps not the gods but the certainty they provided, thereby reducing the scope of their freedom.

This move has long been recognised by those calling for emancipation from divine authority. Perhaps most famously, Nietzsche wondered how humanity would handle the 'nothingness' that followed the death of god. Given that life without the metaphysical comfort of the Christian belief system also meant the death of the subject that had been constituted through this system, Nietzsche asked "How will we console ourselves, the murderers of all murderers!...What festivals of atonement, what holy games will we have to invent for ourselves? Is the magnitude of the deed not too great for us?"32 The ontological security literature in IR suggests that it is. With its "general presupposition...that actors prefer stability and certitude"33 it has squarely placed its focus on the latter aspect of the anxiety paradox. This focus is understandable. The notion that humans are unable, or unwilling, to embrace contingency and radical uncertainty about their being in the world and, instead, harbor a "desire for knowledge"34 capable of providing coherence, consistency and continuity has been widely discussed in philosophy, psychology, psychoanalysis and sociology. Henri Bergson notes that the "natural inclination" of the mind is to proceed "by solid perceptions... and stable conceptions;" 35 Lacan speaks of a human desire to compensate for the 'lack' of a ground on which the Self stands through processes of identification; David Harvey points to the appeal of the 'eternal myth' provided by modernism which "had to redeem us from the 'formless universe of contingency;"” 36 Norbert Elias notes the "longing for something permanent behind the impermanence of all observable data...for something imperishable... as the solid fundament of transient lives," ${ }^{37}$ and Peter Berger and Thomas Luckmann ${ }^{38}$ speak of "symbolic universes"

\footnotetext{
30 Krishna 1994, 508, 514.

${ }^{31}$ Krishna's account of India diagnoses a persistent postcolonial anxiety of a society "trapped in time - former colony but pre-nation” (Krishna 1994, 517).

${ }^{32}$ Cited in Michelsen and Hirst 2013, 105.

33 Browning and Joenniemi 2017, 31.

${ }^{34}$ Huysmans 1998, 236.

${ }^{35}$ Cited in Grosz 2005, 135.

${ }^{36}$ Harvey 1990, 31.

${ }^{37}$ Elias 1992, 128.

${ }^{38}$ Berger and Luckmann 1991 (1966), 119.
} 
which bestow meaning upon death and thereby shelter the individual from the 'ultimate terror' 39 The assumption that humans seek cognitive consistency is also central to work in IR analysing the nature, sources and effects of perceptions, representations and identity. ${ }^{40}$

To be clear, if we take Heidegger's ontology of becoming seriously, the "need to experience oneself as a whole person in time" 41 can never be fully satisfied. It remains, as Lacan would say, a fragile fantasy. ${ }^{42}$ The corresponding understanding of anxiety as an ever-present mood that cannot be switched off renders the subject a perpetual ontological security seeker, in a constant effort to become, yet never really being, ontologically secure. Rather than depicting a subject constantly chasing something that is unobtainable, the ontological security literature holds that humans have devised effective mechanisms, often on the collective level, that control anxiety, to use Giddens' terminology, and make it tolerable. These mechanisms provide a stock of knowledge - "the certainty that phenomena are real and that they possess specific characteristics" 43 - that pushes uncertainty and the contingency of human existence into the background. Ontological security thus works on an emotional level: if anxiety is a feeling of discomfort, even 'terror', the knowledge put in place to control anxiety generates a feeling of comfort - a sense of epistemological peace.

\section{Three Mechanisms: Numbers, Practices, Narratives}

How do humans, upon recognizing that they are masters of their own past and future, attempt to extend themselves beyond 'their' time and re-inscribe their existence into a permanent temporal order outside human intervention? What are those anxiety-controlling mechanisms that enable humans to obtain "cognitive and behavioural certainty" 44 and, hence, the epistemological peace they seek? For the purpose of illustration let me briefly review three: scientific measures using mathematical symbols and logic, routine practice, and narrative.

First, there is the organisation of the temporal dimension through chronos, a linear succession of numbers and intervals that provide a scale into which all events and fluctuations can be neatly embedded. One influential form is 'Western time' that emerged with the project of modernity and is imagined as both passing in a linear fashion of successive and 'empty' units and as a "natural phenomenon", part of an eternal order that exists external to human thought and action. ${ }^{45}$ Designed and supported mechanically and with computers, time becomes cognitively controllable and universally accessible through quantification and mathematical logic, manifest in the Western calendar, the 24-hour clock, and timetables that map out past and future. ${ }^{46}$ On this map, being in time can be recorded, managed and planned, thereby creating a sense of stability, if not certainty. It allows making the future 'knowable' through causal claims and the calculation of risks. Attempts to rationalize the future through mathematical probability, what Ian Hacking ${ }^{47}$

\footnotetext{
${ }^{39}$ Ernest Becker speaks of the need for an “immortality formula” (Becker 1973, 255).

40 Jervis 1976; Hopf 2002.

${ }^{41}$ Mitzen 2006, 342.

42 For an application of Lacan in IR foregrounding the temporal dimension, see Solomon 2012. See also Arfi's discussion of survival as constantly performing a 'leap of faith'.

${ }^{43}$ Berger and Luckmann 1991 (1966), 13.

${ }^{44}$ Mitzen 2006, 342.

${ }^{45}$ Hutchings 2008, 6; Hom 2010.

${ }^{46}$ Elias 1992, 42, 123.

${ }^{47}$ Hacking 1990.
} 
called the 'taming of chance', has become a central feature of the risk society characterizing Western modernity.

The second mechanism, routine practices, is prominently discussed by Giddens ${ }^{48}$ and at the center of much of ontological security scholarship. While the social dimension - the sharing of practices - is important, the significance of routine practices in ordering time resides in the observation that they reduce contingency because of their repetitive nature. That is, they emit a familiarity that comes from being established in the past and carried into the present through formal or informal institutional rules. Although taking place in a moment, a routine act is not a contingent experience but implies temporal continuity by holding the assurance of tradition and the promise to be carried on in the future, whether it is a micro-level routine taking place every day, or a grand ritual taking place once a year. By plucking the individual into what Giddens calls the 'longue duree' of institutional time, routine practices provide a structural frame the individual can hold onto not only for predicting social interactions but to experience the illusion of permanence and, hence, immortality.

The insight that narratives lend human existence a sense of temporal continuity and purpose is well established in the literature. Narratives enable us to meaningfully situate ourselves in past and future and "deal with life as it unfolds over time," ${ }^{49}$ which even leads to the suggesting that humans have a "natural impulse to narrate." 50 Scholars have discussed the power of poetry and scriptures in creating 'spaces of remembrance' that carry being into the 'afterworld,' ${ }^{51}$ or the enduring attraction of utopias and dystopias. ${ }^{52}$ Offering coherent and capturing stories of how life unfolds, or should unfold, beyond the biological life span of individuals is central to both religious doctrines and prominent secular philosophies of, for instance, Kant, Hegel, and Marx. ${ }^{53}$ Although these meta-narratives differ regarding the relative openness of the future, they all picture the world on a path through time and invite us to travel along and to optimize our standing on it. As Hom and Steele ${ }^{54}$ point out, such narratives are often located in the international realm.

These three mechanisms are neither exhaustive ${ }^{55}$ nor mutually exclusive, and they often intersect for enhanced effect. Furthermore, we can see them playing out on the level of both the observed (the social world studied) and the observer (the scholar explaining this world). That is, we can analyze how numbers, routine practices and narratives are mobilized by and guide political actors, and how they are incorporated in scholarly methodologies to tame the contingency of world politics and strengthen the vague contours of IR as an academic discipline. Whatever form they take, as a potent answer to an existentialist problematique and a significant factor in the organisation of social life, anxiety-controlling mechanisms are political, and their creation, maintenance and challenge a matter of politics. At the same time, for anxiety controlling mechanisms to function effectively their invented nature must be forgotten, hidden, or seen as coming out of an extraordinary mind and upheld by respected authorities to dispel doubt of their contingent nature. After all, something seen as a random human construct will not have the sustainable power to tame anxiety. Thus, they must become part of reality, understood

\footnotetext{
${ }^{48}$ Giddens 1984.

49 Ringmar 1996, 451.

${ }^{50}$ White 1987, 1.

${ }^{51}$ Assmann 1999, 39-43.

52 Berenskoetter 2011 and 2014.

53 On immortality ideologies in Western philosophy, see Sheets-Johnstone 2003.

${ }^{54}$ Hom and Steele 2020.

${ }^{55}$ Other prominent mechanisms are role images, maps, or architecture. See also Zarakol 2017.
} 
as "the quality appertaining to phenomena that we recognise as having a being independent of our own volition." 56 The problem is that this reading downplays agency.

\section{The Question of Agency}

As long as we understand anxiety-controlling mechanisms as human creations, and attachment to them as a 'leap of faith,' ${ }^{57}$ agency must be an important part of the picture. In fact, the dialectic noted by Kierkegaard and captured in the anxiety paradox outlined earlier points to more than one kind of agency.

The first kind is emancipatory agency. It is the agency closely tied to the understanding of the enlightenment as an act of liberation. It comes to the fore in the realisation of having a choice and the 'courage to use one's own mind'. Put in temporal terms, it understands that the future and, to some extent, the past is an open terrain. This agency gains its contours in Ulysses' journey and in Adam becoming aware of the ability to act otherwise and, thus, is not simply an agency that just 'is', but an emerging (awareness of having) agency that questions existing worldly constraints and seeks to liberate being from them. It is expressed in a subject that acts upon the recognition that things can be different and confident in its ability to transform one's being in the world. It is a kind of agency that can bring about, in the words of Ernesto Laclau, the "absolute chasm... between the emancipatory moment and the social order that has preceded it." 58 Such radical agency is perhaps most clearly exemplified in the moment of initiating revolt against an existing political order and the system of governance keeping it in place. Actors that disrupt order and shock the system may be celebrated as 'strong' and 'inspirational' leaders, even 'heroes', by those hoping to benefit from the act of liberation, and considered 'foolish', 'dangerous' and 'destructive' by those comfortably embedded in the existing order.

The second kind may be called creative-constitutive agency. It comes to the fore in reaction to an event that undermines existing mechanism and thereby destabilizes conceptions of being in time, in turn generating demand for the creation of (new) mechanisms. ${ }^{59}$ It is the Plato who, having escaped the cave/gods, rebuilds the idea of an eternal order in the vision of the city and places himself within it; it transpires in Anderson's account of collectives who replace the divine order of messianic time with a secular biographical narrative told through the printed press. The IR literature has discussed such acts of (re)creation following wars and the loss, breakdown of familiar political order and systems of meaning they generate. ${ }^{60}$ It can also be found in Francis Fukuyama and Samuel Huntington, whose narratives of global order provided epistemological peace for many post-Cold War minds; in the US government's response to the September 11, 2001 attacks by encouraging habitual behaviour and offering a simplistic 'war on terror' narrative; ${ }^{61}$ or in the revival of religious nationalism in India in response to destabilizing forces of globalization. ${ }^{62}$

The third kind of agency is the muted agency of those who, thrown into a world replete with anxiety stabilising mechanisms, cannot or, rather, do not want to question let alone escape from them. It is agency that fits into, functions within, and sustains existing mechanisms. Doing

\footnotetext{
${ }^{56}$ Berger and Luckmann (1966) 1991, 13.

${ }^{57}$ Arfi 2020.

${ }^{58}$ Laclau 1996, 1.

${ }^{59}$ Often by drawing on an available cultural repertoire (Cash 2020).

${ }^{60}$ Bially Mattern 2005; Jackson 2006; Subotic 2016.

${ }^{61}$ Williams 2005; Solomon 2014.

${ }^{62}$ Kinnvall 2006.
} 
so may "feel agentic," 63 but it merely involves acting out a role in a given script, at best moving along in the process of 'structuration. ${ }^{64}$ It is a reproductive agency and minimally creative in the conservative sense. Studies have shown how political actors chose to sustain existing mechanisms in the form of biographical narratives ${ }^{65}$ or routine practices, ${ }^{66}$ especially in periods of material change, ${ }^{67}$ or navigate tensions between multiple but equally valued narratives/practices through a strategy of avoidance. ${ }^{68}$ In the field of IR, we find this muted agency in realist and liberal theories, where agents are placed on a particular temporal path and must work to optimize their standing on it. More generally, it applies to anyone working within a particular worldview handed down to them, unwilling to question its assumptions and traditional content, and thereby reproducing its epistemic comfort and authority.

These three kinds of agency capture different ways of manifesting being in time, with direct effects on social-political order, and must thus be understood as forms of political agency. The ontological security literature is primarily concerned with the second and third kind, often without differentiating between the two. Indeed, to my knowledge, there are no studies using the ontological security framework that explore and explain phenomena of emancipatory agency in its radical sense. As such, the literature effectively focuses on only one aspect of the anxiety paradox, namely the move to create certainty and gain epistemological peace.

This limitation could be justified by noting the importance of shining light on the creation and the uneventful maintenance of anxiety-controlling mechanisms that structure international relations. While this is a valid position, the reason for neglecting emancipatory agency is not simply due to an analytical preference for explaining the persistence of particular orders or forms of interaction. Rather, it is because the framework has made the human need for stability its core assumption, which renders it ill suited for explaining radical change. In fact, it cannot explain it. As currently devised, the ontological security framework has no place for emancipatory agency because it is stuck with the assumption that the possibility of a radically open future generates a heightened state of anxiety and, as such, ontological insecurity. ${ }^{69}$ More importantly, it links ontological insecurity to inaction. Echoing a psychological argument relayed by Giddens, the assumption is that reflection about the contingency of our lives, especially about our unknowable yet inescapable death, will make subjects "overwhelmed by anxieties"70 and generate a sort of 'deer in the headlight' paralysis. This view is logically accompanied by the view that 'having ontological security' is the precondition for action: whereas "fundamental uncertainty" is paralysing, ${ }^{71}$ having anxiety-controlling mechanisms in place provides the basic trust that allows subjects to 'get on' with their lives. ${ }^{72}$ 'Getting on' here means having the capacity to cope with life's ups and downs, including some change, yet it does not mean seeking radical change. This logic cannot accommodate an agency driven solely by the desire that things should be otherwise, rejecting temporal certainties and accepting an uncertain future, as that would not only amount to

\footnotetext{
${ }^{63}$ Mitzen 2006, 347.

${ }^{64}$ Giddens 1984.

65 Steele 2005, 2008.

66 Mitzen 2006.

${ }^{67}$ Subotic 2016.

${ }^{68}$ Lupovici 2012.

${ }^{69}$ Kinnvall 2006; Steele 2008; Croft 2012; Rumelili 2014.

${ }^{70}$ Giddens 1991, 37.

${ }^{71}$ Mitzen and Schweller 2011, 39.

${ }^{72}$ Mitzen 2006, 346.
} 
choosing a state of insecurity but also fundamentally contradict the premise that certainty is a precondition for action.

One may counter that it is analytically artificial to separate emancipatory and creativeconstitutive agency by holding that all actors seeking to escape existing mechanisms do so while simultaneously setting up new/alternative ones. In other words, disruption and creation occur together, aided by the availability of a variety of different mechanisms to chose from. ${ }^{73}$ This overlaps with studies using the ontological security framework to account for gradual change. ${ }^{74}$ While this is a reasonable step forward, the question remains how we arrive at the moment of transition. Shifting attention to gradual change cannot bypass the fact that the ontological security framework is ill equipped to see or explain the will to shed existing anxiety controlling mechanisms. Ultimately, as Ernesto Laclau ${ }^{75}$ reminds, emancipation is "not an act of creation but instead of liberation". Because it cannot accommodate the desire to open things up, current scholarship on ontological security does not have an intellectual place for agency that simply wants to (and can) escape existing mechanisms, that makes a radical move of liberation, if only for a moment. The conservative bias of the framework not only renders it unsuitable for explaining revolutionary leadership. The inability to logically account for a radical form of agency and chart a way out of an existing configuration is also problematic for normative reasons, especially when looking at cases where anxiety-controlling mechanisms support conflict. ${ }^{76}$ Thus, it is not surprising that the ontological security literature, specifically its assumption that a stable sense of Self is a universal human need and the acceptance of modern strategies to satisfy this need, received stinging criticism. ${ }^{77}$

\section{Radical Agency and Anxiety: Two Possible Avenues}

Rather than discarding the notion of ontological security altogether, let us contemplate the possibility of expanding its scope by probing ontologies that take the temporality of being, and the sources of anxiety, seriously, yet which can accommodate more radical kinds of agency. Going back to philosophy helps. After all, human activity geared towards finding stabilising mechanisms and eradicating inconsistencies and vulnerabilities in their design has long been criticized in Western thought as a betrayal of the emancipatory promise of the enlightenment. Already Kant complained:

"Laziness and cowardice are the reasons why such a large part of mankind gladly remain minors all their lives, long after nature has freed them from external guidance. They are the reasons why it is so easy for others to set themselves up as guardians. It is so comfortable to be a minor."78

\footnotetext{
${ }^{73}$ See Cash 2020; Vieira 2017.

${ }^{74}$ Berenskoetter and Giegerich 2010; Rumelili 2015.

${ }^{75}$ Laclau 1996, 1.

${ }^{76}$ Mitzen 2006; Rumelili 2015.

77 Rossdale 2015a; Lebow 2017. Reminiscent of the earlier poststructuralist critique of naturalised notions of identity, the charge is that the ontological security literature operates with a modern form of subjectivity as an ideal, which is problematic both empirically and ethically as it forecloses the reality and possibility of more open forms of subjectivity

${ }^{78}$ Kant 1959, emphasis added.
} 
Kant's dismay about the easiness with which humans succumb to epistemological peace is echoed by a long list of Western thinkers including Hegel, Marx, Nietzsche, Bergson, Heidegger, Horkheimer and Adorno, Foucault, Derrida, Butler, Bauman - the list could go on. Crudely put, the critique has two themes: that attachment to those mechanisms (i) limits individual freedom and creativity and (ii) hampers authentic being. While quite different in character, these two concerns meet in the critique that the propensity of humans to surround themselves with a seemingly comforting structure constrains capacity for and, indeed, prevents a more profound kind of agency. Scientific time, routine practices and narratives may function as anxiety controlling mechanisms, but they prevent the Self from 'true' being and acting. Such diagnoses usually entail a call for resisting, intervening in and escaping from, indeed overthrowing these mechanisms and the social systems they carry.

Understood in temporal terms, it calls for a kind of agency attached to kairos, which stands for discontinuity and the suspension of order. It is an in-between space of absolute freedom and, thus, contingency. ${ }^{79}$ As such, it captures the temporal form of the emancipatory moment and also designates a particular experience of time. As Kim Hutchings shows, kairos has been discussed by thinkers from Machiavelli to Arendt and is generally understood as designating a "transformational time of action." 80 In the same vein, kairotic agency is seen as empowered by a positive attitude towards the contingency of fortune, the ability to learn and reflect and a "fundamental human capacity for renewal." ${ }^{81}$ Incorporating such a radical form of agency into the ontological security framework is a significant challenge and beyond the scope of this article. However let me outline two avenues for thinking about kairotic agency. Although quite different in character, they meet in discarding the reading of anxiety as a background sentiment that has to be controlled.

The first avenue emphasises the incomplete nature of being and the need to embrace the productive potential of the contingent experiences underpinning anxiety. It has some similarities with the postmodern take of being as, in the words of David Harvey, swimming, even wallowing, in the chaotic currents of change and to embrace fragmentation and ephemerality "in an affirmative fashion." 82 It views social order as incomplete and full of tensions and contradictions, with agency emerging through the cracks of these (dis)orders and gaining life through plural and fleeting encounters. It is captured in Judith Butler's conception of performative agency subverting existing systems through creative processes of resignification, ${ }^{83}$ or Ned Lebow's emphasis on role-playing as "a form of play that invites subjunctive "as-if” mechanisms of disguise, substitution and recombination." 84 These accounts conceive of agency primarily through existing social arrangements rather than the temporal dimension, however.

More useful is Henri Bergson's conception of a Self that bundles contingent and multiple worldly experiences into a distinct sense of what he calls "inner time" through a process of "creative evolution." 85 This inner time is grounded in the intensity of the sensations, triggered by worldly events, which collapse past, present and future into a singular but not homogenous conception of being in time. Bergson captures this creative process through the concept of 'duration', “a mode of temporal synthesis that...knits temporal dimensions together as in a

\footnotetext{
79 O Murchadha 1999, 106.

${ }^{80}$ Hutchings 2008, 5.

${ }^{81}$ Ibid., 33, 50, 62.

${ }^{82}$ Harvey 1991, 44.

${ }^{83}$ Butler 1990.

${ }^{84}$ Lebow 2012, 285.

${ }^{85}$ See Guerlac 2006.
} 
melody" Guerlac. ${ }^{86}$ Crucially, the fusion of diverse experiences is a source of energy, and when drawing on these experiences the Self is "closer to dreaming than to knowing" and its movements take the form of "dancing." 87 This account of agency is not goal-oriented or about making rational choices, instead it highlights intuition and passion. ${ }^{88}$ In its expression it is similar to the Nietzschean conception of The Dancer discussed by Chris Rossdale, whereby the dance is understood as "a metaphor for a mobile and creative radical subjectivity." 89 The Bergsonian perspective grounds this figure in the temporal dimension and opens the door to a conceptualisation of being distinct from social order and not paralysed by anxiety: because contingent experiences are fused into an evolving "inner time" that serves as a creative force, the Self is not bothered by the indeterminacy of the future. In fact, it does not worry about the future or even conceive of the future as a significant space, but dances seemingly aimlessly through the world, which lends it the potential for radical agency.

The second avenue brings us back to Heidegger and his suggestion that anxiety can be suspended in a moment of 'being-towards-death', which endows the Self with the resolve [Entschlossenheit] of kairotic agency. ${ }^{90}$ This agency is about the act of stepping out of the Man and, in contrast to accounts that see the future as a continuation of the past, separates the former from the latter, thereby opening the future as future. ${ }^{91}$ The Heideggerian avenue thus maintains the importance of the future and the inevitability of death as the reference for conceptualising being and, thus, agency. It has to do so because in Heideggerian logic the uncertain future is the primary source of anxiety and generates the condition that prevents being from fully being itself. Consequently, an account of kairotic agency must reconfigure how being relates to the future and, in particular, the possibility of death. This is not the place to explore what exactly 'facing death' involves, except to note that for Heidegger it designates a state of mind in which death is accepted as a possibility and integrated into being as finite and, thus, whole. ${ }^{92}$ It is a moment in which conscience calls upon being to accept the "simplicity of fate," 93 to see its future as open and to clearly identify possible forms this future might take, including death. In this reconfiguration of being as being-towards-death, anxiety is suspended. More precisely, anxiety is replaced by fear, which pulls the Self out of its "complacent absorption in everydayness" 94 and allows being to "find itself." 95 For Heidegger this state of what he calls authentic being is an exception, though, a rare occurrence that emerges suddenly and unexpectedly and is experienced as a moment of singularization [Vereinzelung]. ${ }^{96}$ In this moment being leaves behind the existing order of things and embraces its future as a space of distinct possibilities, including the possibility of revolution.

\section{Conclusion}

\footnotetext{
${ }^{86}$ Ibid., 66.

${ }^{87}$ Ibid., $47 \mathrm{ff}$.

${ }^{88}$ Grosz 2005; Guerlac 2006.

${ }^{89}$ Rossdale 2015b, 129.

${ }^{90}$ Browning and Joenniemi (2017) also end up with this reading.

${ }^{91}$ O Murchadha 1999, 27.

92 Heidegger spends much of the second part of Being and Time grappling with this possibility.

${ }^{93}$ O Murchadha 1999, 109.

${ }^{94}$ Guignon 2006, 282.

95 Heidegger 1953, 250f, 268, 308.

${ }^{96}$ Ibid., 187ff, 336ff
} 
This article attempted to contribute to scholarship on ontological security by making three conceptual interventions. First, through Heidegger and Kierkegaard, it brought to the forefront the temporal structure of the concept of anxiety, noted its status as a foundational background sentiment, or mood, of the human condition, and pointed to the paradoxical trait of reflexive humans to both being drawn to and seeking to escape anxiety. Second, it noted that the current literature on ontological security grounds its logic of human behavior, in particular the need to construct and maintain anxiety-controlling mechanisms, in one aspect of this paradox, namely the search for certainty.. It argued that this conception of ontological security has significant implications for agency as under this logic the framework cannot account for emancipatory agency. Third, drawing on Bergson and Heidegger, the article outlined two avenues of thought that open the door for more radical forms of agency for temporal beings.

Scholarship on ontological security currently appears to be trapped in the conservative bias of the framework, which raises the question whether it faces an aporia - "a self-engendered paradox beyond which it cannot press" 97 - or whether accounts of radical/kairotic agency can be integrated into the framework. For IR scholars the stakes are not simply philosophical but whether the ontological framework is useful for seeing and explaining phenomena of radical action and change in world politics. The two avenues sketched towards the end dissolve the anxiety paradox by either embracing or suspending anxiety. This does not make them necessarily incompatible, in fact there are fruitful points of connection: ${ }^{98}$ both work in the phenomenological tradition and both highlight the 'internal' configuration of temporal being, a form of what Kirkegaard termed the 'subjective spirit'. And there might be ways of combining Bergson's view of how the experience of contingency is a source of creative energies with Heidegger's emphasis on being as oriented towards the future and, especially, death. In any case, the central question is whether kairotic agency signifies an ontologically secure being. One might argue that a being that accepts contingency and turns it into a productive life force is the fullest, perhaps the only expression of ontologically secure being. Then again, if ontological security is about gaining a stable sense of Self through temporal continuity, can it integrate a revolutionary agency, which by default celebrates instability and discontinuity? The alternative route would be to entertain an agency that embraces ontological insecurity and, thus, the incomplete nature of being. In this vein, the most productive approach might be to rebuild the framework on a full appreciation of the anxiety paradox. Recovering the neglected side of the dialectic identified by Kirkegaard, namely being drawn to freedom's possibility, would require balancing the yearning for certainty with a penchant for curiosity. Until then, the question of radical agency shakes the intellectual foundations of ontological security scholarship.

\section{References}

Anderson, Benedict. 2006. Imagined Communities. Revised edition. London: Verso.

Assmann, Aleida. 1999. Erinnerungsräume. München: C. H. Beck.

Berenskoetter, Felix. 2011. "Reclaiming the Vision Thing: Constructivists as Students of the Future.” International Studies Quarterly 55 (3):647-668.

\footnotetext{
${ }^{97}$ Doty 1997, 375.

${ }^{98}$ On the link between Heidegger and Bergson, see Massey 2016.
} 
Berenskoetter, Felix. 2014. “Parameters of a National Biography.” European Journal of International Relations 20 (1):262-288.

Berenskoetter, Felix. 2018. “Deep Theorizing in International Relations.” European Journal of International Relations 24 (4):814-840.

Berenskoetter, Felix and Bastian Giegerich. 2010. "From NATO to ESDP: A Social Constructivist Analysis of German Strategic Adjustment after the End of the Cold War." Security Studies 19 (3):407-452.

Berger, Peter and Thomas Luckmann. 1991 [1966]. The Social Construction of Reality. Hardmondsworth, UK: Penguin Books.

Becker, Ernest. 1973. The Denial of Death. New York: The Free Press.

Butler, Judith. 1990. Gender Trouble. London: Routledge

Croft, Stuart. 2012. “Constructing Ontological Insecurity: The Insecuritization of Britain’s Muslims.” Contemporary Security Policy 33 (2):219-235.

Doty, Roxanne L. 1997. “Aporia: A Critical Exploration of the Agent-Structure Problematique in International Relations Theory.” European Journal of International Relations 3 (3):365392.

Elias, Norbert. 1992. Time: An Essay. Oxford: Blackwell.

Emirbayer, Mustafa and Ann Mische. 1998. “What is Agency?” The American Journal of Sociology 103 (4):962-1023.

Epstein, Charlotte. 2013. “Theorizing Agency in Hobbes’ Wake: The Rational Actor, the Self, or the Speaking Subject?” International Organization 67 (2):287-316.

Flockhart, Trine. 2017. “The problem of change in constructivist theory: ontological security seeking and agent motivation.” Review of International Studies 42 (5):799-820.

Giddens, Anthony. 1984. The Constitution of Society. Berkeley: University of California Press.

Giddens, Anthony. 1991. Modernity and Self-Identity. Cambridge: Polity Press.

Grosz, Elizabeth. 2005. Time Travels. Durham, NC: Duke University Press.

Guerlac, Suzanne. 2006. Thinking in Time. Ithaca, NY: Cornell University Press.

Gunnell, John G. 1987. Political Philosophy and Time. Chicago: University of Chicago Press. 
Hacking, Ian. 1990. The Taming of Chance. Cambridge: Cambridge University Press.

Hannay, Alastair. 2014. “Translator’s Introduction.” In The Concept of Anxiety, edited by Søren Kierkegaard, ix-xxvii. New York: Liveright.

Harvey, David. 1990. The Condition of Postmodernity. Cambridge, MA: Blackwell.

Heidegger, Martin. (1927) 2001/1953. Sein und Zeit. Tübingen: Max Niemeyer Verlag.

Hom, Andrew R. 2010. "Hegemonic Metronome: the ascendancy of Western standard time.” Review of International Studies 36 (4):1145-1170.

Hopf, Ted. 2002. Social Construction of International Politics. Ithaca: Cornell University Press.

Horkheimer, Max and Theodor Adorno. (1947) 1998. Dialektik der Aufklärung. Frankfurt: Fischer.

Hutchings, Kimberly. 2008. Time and World Politics. Manchester: Manchester University Press.

Huysmans, Jef. 1998. "Security! What Do You Mean? From Concept to Thick Signifier.” European Journal of International Relations 4 (2):226-255.

Jackson, Patrick T. 2006. Civilizing the Enemy. Ann Arbor: University of Michigan Press

Jervis, Robert. 1976. Perception and Misperception in International Politics. Princeton: Princeton University Press.

Kant, Immanuel. 1959. Foundations of the Metaphysics of Morals, and What Is Enlightenment? Indianapolis: Bobbs-Merrill.

Kinnvall, Catarina. 2004. "Globalization and Religious Nationalism: Self, Identity, and the Search for Ontological Security.” Political Psychology 25 (5):741-767.

Kinnvall, Catarina. 2006. Globalization and Religious Nationalism in India. London: Routledge.

Kirkegaard, Søren. (1844) 2014. The Concept of Anxiety. Translated by Alastair Hannay. London and New York: Liveright.

Krishna, Sankaran. 1994. "Cartographic Anxiety: Mapping the Body Politic in India." Alternatives: Global, Local, Political 19 (4):507-521.

Laclau, Ernesto. 1996. Emancipation(s). London and New York: Verso.

Lebow, Richard N. 2012. The Politics and Ethics of Identity. Cambridge University Press. 
Lebow, Richard N. 2017. National Identities and International Relations. Cambridge: Cambridge University Press.

Lupovici, Amir. 2012. “Ontological Dissonance, Clashing Identities, and Israel’s Unilateral Steps towards the Palestinians.” Review of International Studies 38 (4):809-833.

Massey, Heath. 2016. The Origin of Time: Heidegger and Bergson. Albany, NY: SUNY Press.

Michelsen, Nicholas and Aggie Hirst. 2013. "Introduction: International Relations and the Death of God.” Millennium: Journal of International Studies 42 (1):103-113.

Mitzen, Jennifer. 2006. "Ontological Security in World Politics. State Identity and the Security Dilemma.” European Journal of International Relations 12 (3):341-370.

Murchadha, Felix O. 1999. Zeit des Handelns und Möglichkeit der Verwandlung. Würzburg: Königshausen \& Neumann.

Odysseos, Louiza. 2002. "Radical phenomenology, ontology and international political theory.” Alternatives 27 (3):373-405.

Odysseos, Louiza. 2007. The subject of coexistence. Minneapolis: University of Minnesota Press.

Ringmar, Erik. 1996. “On the Ontological Status of the State.” European Journal of International Relations 2 (4):439-466.

Rossdale, Chris. 2015a. "Enclosing Critique: The Limits of Ontological Security.” International Political Sociology 9 (4):369-386.

Rossdale, Chris. 2015b. “Dancing Ourselves to Death: The Subject of Emma Goldman’s Nietzschean Anarchism.” Globalizations 12 (1):116-133.

Rumelili, Bahar. 2015. "Identity and Desecuritisation: the pitfalls of conflating ontological and physical security.” Journal of International Relations and Development 18 (1):52-74.

Solomon, Ty. 2014. “Time and Subjectivity in World Politics.” International Studies Quarterly 58 (4):671-681.

Steele, Brent J. 2005. "Ontological Security and the power of self-identity: British neutrality and the American Civil War.” Review of International Studies 31 (3):519-540.

Steele, Brent J. 2008. Ontological Security in International Relations. London: Routledge.

Subotic, Jelena. 2016. "Narrative, Ontological Security, and Foreign Policy Change.” Foreign Policy Analysis 12 (4):610-627. 
Vieira, Marco. 2017. “(Re-)Imagining the 'Self’ of Ontological Security: The Case of Brazil’s Ambivalent Postcolonial Subjectivity.” Millennium: Journal of International Studies 46 (2):142-164.

Wendt, Alexander. 1987. “The agent-structure problem in international relations theory.” International Organization 41 (3):335-370.

White, Hayden. 1987. The Content of the Form. Baltimore: Johns Hopkins University Press.

Williams, Michael C. 2005. "What is the National Interest? The Neoconservative Challenge in IR Theory.” European Journal of International Relations 11 (3):307-337.

Zarakol, Ayse. 2017. “States and Ontological Security: A Historical Rethinking.” Cooperation and Conflict 52 (1):48-68. 